\title{
A STUDY OF THE COMPOSITION OF THE ALKALOIDS OF ERGOTS OF THE ERGOMETRINE STRAIN
}

A. N. Ban'kovskaya, L. D. Vechkanova, and A. I. Ban'kovskii

Khimiya Prirodnykh Soedinenii, Vol. 6, No. 3, pp. 381-382, 1970

UDC 547.945 .1

A chemical study of the ergotamine strain has been reported previously [1]. In this paper we give the results of a study of ergots of the ergometrine strain.

Ergots collected from production crops of the experimental base of VILR [All-Union Scientific-Research Institute for Medicinal Plants] (Moscow region) were used. The alkaloids were extracted from the comminuted ergots with dichloroethane, from which they were exhaustively extracted with tartaric acid solution. The tartaric extracts were made alkaline with ammonia and the bases were extracted with chloroform. The extracts were dried over sodium sulfate and the solvent was evaporated off to small volume. On standing in the cold, white crystals deposited with $\mathrm{mp} 159-160^{\circ} \mathrm{C}$ (from methyl ethyl ketone and ethyl acetate) with the composition $\mathrm{C}_{19} \mathrm{H}_{23} \mathrm{O}_{2} \mathrm{~N}_{3},[\alpha]_{\mathrm{D}}^{20}+41^{\circ}(\mathrm{c} 1.8$, ethanol). The base is readily soluble in methanol, ethanol, and acetone, and moderately soluble in benzene and water; it forms a hydrochloride with $\mathrm{mp} 175^{\circ} \mathrm{C}$ (decomp.), a hydrobromide with $\mathrm{mp} 239-240^{\circ} \mathrm{C}$ (decomp), and an oxalate with $\mathrm{mp} 189-190^{\circ} \mathrm{C}$ (decomp). From its composition, its melting point, and that of its salts, a mixed melting point with an authentic sample, and its IR spectrum [2] it was identified as ergometrine. The mother liquor, after the isolation of the ergometrine, yielded a second base with the composition $\mathrm{C}_{19} \mathrm{H}_{23} \mathrm{O}_{2} \mathrm{~N}_{3}, \mathrm{mp}_{193}-194^{\circ} \mathrm{C}$ (decomp), $[\alpha]_{\mathrm{D}}^{20}+412^{\circ}$ (c 0.5 , chloroform), readily soluble in ethanol, methanol, and acetone, and sparingly soluble in chloroform and water, giving a hydrochloride with $\mathrm{mp} 175-180^{\circ} \mathrm{C}$ (decomp). From its composition, melting point, and those of its salts, and a mixed melting point with an authentic sample it was identified as ergometrinine.

\section{REFERENCES}

1. A. N. Ban'kovskaya and A. I. Ban'kovskii, Lekarstvennye rasteniya, Khimiya, 15, $219,1969$.

2. A. Hofmann, Die Mutterkornalkaloide, Enke Stuttgart, 1964.

\section{January 1970}

All-Union Scientific-Research Institute of Medicinal Plants 